\title{
Breast Cancer cN0 TNM Finding v6 and v7
}

National Cancer Institute

\section{Source}

National Cancer Institute. Breast Cancer cNO TNM Finding v6 and v7. NCI Thesaurus. Code C73347.

Breast cancer with no regional lymph node metastasis. (from AJCC 6th and 7th Eds.) 